\title{
Students Participation and Perception in Threaded Online Discussion
}

\author{
Husniyatus Salamah Zainiyati ${ }^{1}$, Dhimas Dwi Nugraha Hadistya ${ }^{2}$ \\ Universitas Islam Negeri Sunan Ampel Surabayal, Newcastle University ${ }^{2}$ \\ Indonesia ${ }^{1}$, England ${ }^{2}$
}

\begin{abstract}
Many terms used for distance learning utilizing internet namely, on-line learning, $e$ learning, internet-enable learning, virtual learning, virtual classroom or web based learning. One of the uses of it is for online discussion using online threaded portal. Using online threaded discussion, the study aims to find out the participation and perspective of the students in using online media to conduct a discussion. The research chooses Muhammadiyah University of Malang's students as the participants. The students' participation was determined by the level of interactivity of the students during discussion, yet the perspective was compiled through the questionnaire administered. This study applied quantitative method to seek the students' participation by adopting Thomas' framework to count the level of interaction in each message and further this data will be explained qualitatively. The result of the study found that the percentage of the students commenting on threaded online discussion is still low. Out of 20, only 9 commented in the first group whereas the second group from 23 students only 20 who join the discussion. Furthermore, the majority of the students hold negative perception toward threaded discussion.
\end{abstract}

Key Words: Threaded online discussion, Distance Learning, participation, perception.

\section{INTRODUCTION}

Many terms used for distance learning utilizing internet namely, on-line learning, e-learning, internetenable learning, virtual learning, virtual classroom or web based learning. One of the uses of it is for online discussion using online threaded portal. It is worth mentioning that the online discussion is divided into two types: synchronous and asynchronous/threaded [1].

The research applies the use asynchronous/threaded system, as the asynchronous environment will offer the participants the opportunity to take part in collaborative discussion [2]. The benefit of asynchronous compared to synchronous is that asynchronous provides more time for students to re-evaluate their answer before submitting it.

There are two research questions, namely 1)How is the students' interaction in threaded online discussion? and 2) What is the perception of the students toward threaded online discussion?

\section{RESEARCH METHOD}

This study aims to seek the participation and perception of students in threaded online discussion. The researcher selected students as a sample from a Muhammadiyah University in Malang East Java Indonesia.

This study used Proboard as a threaded forum to perform online discussion. Proboard is free forum hosting service which has many features that are simple to use. There are four main features that can be observed in the homepage. First is General Board thread that will redirect the user to the General Board page. Second is a thread column which explains the amount of thread. Third is the post column, which

informs the user of the number of posts. The last is the Forum Information and Statistics board which illustrates the summary of the thread, post and the users currently occupying the forum.

Content analysis is implemented to measure the students' participation. In this case, the content will determine the level of interactivity of students.This study implemented both quantitative and qualitative approaches. In other words, this study will determine students' participation by counting students' level of interaction.

The second research question in this study attempts to seek students' perception toward online discussion. This perception was obtained from the questionnaire as a secondary instrument.

\subsection{Data Collection}

There were 45 students who were divided by their attendance list number: numbers 1-22 belong to Class A, whereas the remaining belongs to Class B, which means that Class A consists of 22 students.

The researcher explained the use of threaded forum to conduct a group discussion. The class began 
by separating two classes; Class A and B and they returned back home. They got to choose between 2 topic, Sunda Trait Bridge or Malang City.

There will be 4 categories to be analysed using content analysis as explained by Thomas, first is Independent level: message makes no reference to other students' messages, second is quasi-interactive level: message refers to other students' messages, but only as a preliminary point of reference before the student continues with their own isolated analysis, third is interactive (elaborative) level: message refers to another student's message and further develops the subject, and the last is interactive (negotiating) level: message refers to another student's message and engages in negotiation or debate.

\section{FINDINGS}

With the topic of Sunda Trait Bridge, Class A has 22 students to give their shot in the online discussion. Among 22 students, there are only 19 of them succeed to register and have an account into the threaded forum. Sadly, the group was only dwelled by 13 students who posted a comment. In detail there were 18 post in total, 15 independent, 1 quasiinteractive, 1elaborative, 1 negotiating

Moving to the class B discussing Malang City as the topic, in the second big group, there are 23 students who should have joined the online forum, yet there were only 20 students register in the forum. Surprisingly, all of them who succeed to register commented on the post although only 3 of the students dominating with 35 comments out of 47 comments posted. In detail there are 26 independent posts, 3 quasi-interactive, 6 elaborative, 12 negotiating.

Next is the perception of the students got from the questionnaire, shown below:

Moving to the next set of question about the difficulty the students had in online discussion in number 13 of the questionnaire among 26 students who submitted the questionnaire, there are 13 students who admitted that they had technical issue with the online forum. 10 of them could not use the online forum, 1 student find it difficult to refer to particular post such us quoting some post, and 2 students had a bad internet connection. The rest of the students faced more likely in the discussion. 2 students stated that they could not understand their friends' comments. 3 students did not really understand the question asked in material. Lastly, 3 students did not know what to say.

\section{DISCUSSION}

The finding regarding students' perceptions was that most of them hold a negative perception of online discussion, as they frequently had to deal some difficulties. This study breaks down the discussion into sub units below:

\subsection{Students' Interaction}

The presence of the teacher in online threaded discussion seems less dynamic since it is categorized as web course where material, discussion, consultation, task and test fully done through online [3] without having face to face session with the teacher. In this study, the teacher could only give face to face guidance at the beginning of the session. Although there is a question and answer thread in the forum, students barely used it to communicate with the teacher. By giving guidance, the teacher should be responsible for keeping the discussion in the online forum on track [4]. However, if the teacher fails to do so, the online discussion will be difficult to run. Consequently, this problem may impede the students' from actively participating in online forum.

There is a high probability for a technical issue to occur in an online discussion forum, especially if the study is conducted in an area where the internet connection is poor. [5], one of the most trusted sites in Indonesia, reported that Indonesia was in 122 in the world in terms of its internet connection. The second reason might be the inability of the students to use threaded forum.

\begin{tabular}{|l|l|}
\hline 1 & $\begin{array}{l}\text { Do you agree that online discussion is enjoyable? 3 students } \\
\text { answered strongly agree, 16 agree,6disagree, 1 strongly } \\
\text { disagree }\end{array}$ \\
\hline 2 & $\begin{array}{l}\text { Do you agree that online discussion gives you more chance } \\
\text { to participate in the discussion? 5 students answered } \\
\text { strongly agree, 18 agree,3disagree, 1 strongly disagree }\end{array}$ \\
\hline 3 & $\begin{array}{l}\text { Do you agree that online discussion is better than classroom } \\
\text { discussion? no student answered strongly agree, 4 } \\
\text { agree,20disagree,2 strongly disagree }\end{array}$ \\
\hline 4 & $\begin{array}{l}\text { Is it easy for you to give your opinion in online discussion? } \\
5 \text { students answered yes, 6 not always, 15 not at all }\end{array}$ \\
\hline 5 & $\begin{array}{l}\text { Do you agree that online discussion is more difficult than } \\
\text { classroom discussion? 5 students answered strongly agree, } \\
16 \text { agree,3 disagree, 2 strongly disagree }\end{array}$ \\
\hline 6 & $\begin{array}{l}\text { Do you agree that most of your classmates participate better } \\
\text { in online discussion? no student answered strongly agree, } 2 \\
\text { agree,17 disagree, 7 strongly disagree }\end{array}$ \\
\hline 7 & $\begin{array}{l}\text { When you are in an online discussion, do you feel afraid to } \\
\text { give your opinion? 3 students answered yes, 10 not always, } \\
13 \text { not at all }\end{array}$ \\
\hline 8 & $\begin{array}{l}\text { Do you feel that everything about online discussion is } \\
\text { confusing? 10 students answered yes, 11 only some of them, } \\
5 \text { not at all }\end{array}$ \\
\hline 9 & $\begin{array}{l}\text { Do you agree that sometimes classroom discussion can be } \\
\text { threatening, so you are hesitant to give your opinion? 2 } \\
\text { students answered yes, 10 not always, 11 not at all }\end{array}$ \\
\hline
\end{tabular}

\begin{tabular}{|l|l}
\hline 10 & Is the teacher more helpful during online discussion? 1
\end{tabular} 


\begin{tabular}{|l|l|}
\hline & students answered yes, 26 no \\
\hline 11 & $\begin{array}{l}\text { Is the online discussion system convenient to use? 5 } \\
\text { students answered yes, 13 not really, 8 not at all }\end{array}$ \\
\hline 12 & $\begin{array}{l}\text { In terms of scoring and evaluation, do you think online } \\
\text { discussion is fairer in giving credit to active students and } \\
\text { passive ones? 10 students answered yes, 6 not always, 10 } \\
\text { not at all }\end{array}$ \\
\hline
\end{tabular}

This study used Proboard as asynchronous online website. The features in Proboard are more or less the same as Kaskus, the most popular online forum in Indonesia. The initial assumption is probably that some of the students are already familiar with the aforementioned website style. Yet, the hierarchical structure in threaded online portal makes it difficult to promote more interactive dialogue that the students can follow

[6]. Eventually, it leads the students to an interrelated monologue [7]. As evidence, in two classes, most of the messages which appeared in threaded discussion were independent ones. Therefore, this proves that the students are only likely to answer the task without bothering to reply to the other post.

The last possibility for the lack of students' participation in an online discussion is that the amount of time the students need to respond to the main task, as well as to their friend's post.

Additionally, they need to interact with others by responding to the other's post. Several researchers, such as [8], [9], and [10] agree with this finding. This study shows that most of the students did not use their time well and ended up only answering the task without interacting with each other, which caused less participation.

\subsection{Students' Perception}

According to the results of the questionnaire, most of the students confirmed a negative response toward online discussion. Nevertheless, online discussion also has several benefits according to them. Overall, there are three factors contributing to students' perception toward online discussion: technical issues, the atmosphere and interaction issue.

In term of technicality, most students gave negative responses to the questions related to technology, such as facility, internet connection and the procedure regarding online discussion. [11] in their study determined that distance educators in most Asian countries face similar issues of poor internet and online infrastructure.

In contrast with the problem of technicality, most of the students have a positive perception regarding the atmosphere of the online discussion. From the questionnaire, sixty of them stated that they enjoyed the process of online discussion and only seven of them did not find the process enjoyable. In addition, atmosphere scored a positive value towards online discussions. It should be noted that by atmosphere, it means comfort [12]. According to [6], researchers believe that the online discussion process frees learners from time and space constraints, providing ample possibilities for communication.

Students' perception regarding the interaction pattern during online discussion is divided into two. Half of the students have a negative perception while the other half has a positive perception toward the interaction pattern. Among students themselves, they discovered that it was difficult to respond to each other and therefore could not develop the topic in the same direction. According to [12], a commonly reported disadvantage of online discussions is that participants can rarely obtain immediate feedback from others because not all of the students participate at the same time. Furthermore, some students relied on Google Translate to overcome their language insecurities yet it ruined their English. Consequently, their other friends were not able to provide a proper response in the forum for their arguments.

Somehow, in terms of participation, a number of students believe that online discussion could promote balanced participation. Eighteen students considered that online discussion gave them more chance to participate because they had time to think of their answers and elaborate on their reasoning. Indeed, online discussions would be more helpful if the discussions intend to create more equal opportunity for all group members [13] or to avoid aggression.

\section{CONCLUSION}

This research conducted from an Indonesian context, in other words we cannot generalise the result of this study to English language teaching and learning. There are many factors limiting this study. For instance, the use of the material could also impact on the students' participation. Lastly is the use of Proboard as a threaded forum. Among many suggested, Proboard is the most straightforward one; however, it is not really attractive; therefore the use of another forum could be another consideration. For future research, it is suggested that both researcher and teacher could use more threaded discussion in English as a foreign language teaching and learning. The use of threaded forum could also be observed as a complimentary means to enhance the students' performance. In addition, long term experimental research could also be undertaken to ascertain another solution regarding the inferiority of the students in participating in a discussion, as well as an imbalanced number of students who participate in a group discussion. 


\section{REFERENCES}

[1] Hosseini, S, B. (2012). Asynchronous Computer-Mediated Corrective Feedback And The Correct Use Of Prepositions: Is It Really Effective?. Turkish Online Journal of Distance Education-Tojde October 2012 Issn 1302-6488 Volume: 13 Number: 4 Article 6. Tehran.

[2] Palloff, R. M., \& Pratt, K. (2011). The excellent online instructor: Strategies for professional development. John Wiley \& Sons.

[3] Zainiyati,H.S.Pengembangan Media Pembelajaran berbasis ICT, Konsep dan aplikasi pada Pembelajaran PAI, publisher: Kencana, 2017

[4] Beaudin, B. P. (1999). Keeping online asynchronous discussions on topic.Journal of Asynchronous Learning Networks, 3(2), 4153.

[5] Kompas.Com.(2008).KaskusWajah Baru. (Retrieved on $12^{\text {th }}$ of August, 2015)

[6] Thomas, M. J. (2002). Learning within incoherent structures: The space of online discussion forums. Journal of Computer Assisted Learning, 18(3), 351-366.

[7] Meyer, K. A. (2003). Face-to-face versus threaded discussions: The role of time and higher-order thinking. Journal of Asynchronous Learning Networks,7(3), 55-65.

[8] Jonassen, D. H., \& Kwon II, H. (2001). Communication patterns in computer mediated versus face-to-face group problem solving. Educational technology research and development, 49(1), 35-51.

[9] Olaniran, B. A., Savage, G. T., \& Sorenson, R. L. (1996). Experimental and experiential approaches to teaching face- to- face and computer- mediated group discussion.

[10] Baggaley, J., Belawati, T., Malik, N., \& Ng Lee Hoon, M. (2007). The PANdora model of collaborative distance education research.Distance Education, 28(2), 245-252.

[11] Wang, Q., \& Woo, H. (2007). Comparing asynchronous online discussions and face- toface discussions in a classroom setting. British Journal of Educational Technology,38(2), 272-286.

[12] Warschauer, M. (2006). Laptops and literacy: Learning in the wireless classroom. Teachers College Pr.

[13] Curtis, D. D., \& Lawson, M. J. (2001).Exploring collaborative online learning. Journal of Asynchronous learning networks, 5(1), 21-34.

[14] Eklund, J. \&Eklund, P. (1997). Collaboration and networked technology: A case study in teaching educational computing. Journal of Computing in Teacher Education, 13, 14-19.

[15] list25.com (2012) The Most Influential Language in the World. (retrieved on $10^{\text {th }}$ of August, 2015)

[16] Newman, D. R., Webb, B., and Cochrane, C. A Content Analysis Method to Measure Critical Thinking in Face-to-Face and Computer Supported Group Learning, 1999.

[15] Shapley, P. On-line Education to Develop Complex Reasoning Skills in Organic Chemistry. JALN,Vol. 4, No. 2, 2000. 